\title{
Improving the extraction of Ara h 6 (a peanut allergen) from a chocolate- based matrix for immunosensing detection: Influence of time, temperature and additives
}

\author{
Rita C. Alves $^{\mathrm{a}, \mathrm{b}, *}$, Filipa B. Pimentel ${ }^{\mathrm{b}}$, Henri P.A. Nouws ${ }^{\mathrm{a}}$, Túlio H.B. Silva ${ }^{\mathrm{a}, \mathrm{c}}$, M. Beatriz P.P. Oliveira ${ }^{\mathrm{b}}$, \\ Cristina Delerue-Matos ${ }^{\mathrm{a}}$
}

a REQUIMTE/LAQV, Instituto Superior de Engenharia do Instituto Politécnico do Porto, Rua Dr. António Bernardino de Almeida, $4200-072$ Porto, Portliga
${ }^{\mathrm{b}}$ REQUIMTE/LAQV, Departamento de Ciências Químicas, Faculdade de Farmácia, Universidade do Porto, Rua de Jorge Viterbo Ferreira, 228, 4050-313Porto Portugal
c Instituto Federal Goiano, Campus Morrinhos, Rodovia BR153, KM633-Zona Rural, Morrinhos-GO, 75650-000, Brazil

Keywords:
Peanut
Allergen
Ara h 6
Extraction
Chocolate
Food
Biosensor
Voltammetric

A B S T R A C T

The extraction of Ara h 6 (a peanut allergen) from a complex chocolate-based food matrix was optimized by testing different temperatures, extraction times, and the influence of additives ( $\mathrm{NaCl}$ and skimmed milk powder) in a total of 36 different conditions. Analyses were carried out using an electrochemical immunosensor. Three conditions were selected since they allowed the extraction of the highest levels of Ara h 6. These extractions were performed using $2 \mathrm{~g}$ of sample and $20 \mathrm{ml}$ of $\mathrm{Tris}-\mathrm{HNO}_{3}(\mathrm{pH}=8)$ containing: a) $0.1 \mathrm{M} \mathrm{NaCl}$ and $2 \mathrm{~g}$ of skimmed milk powder at $2 \mathrm{PC}$ for $60 \mathrm{~min}$; b) $1 \mathrm{M} \mathrm{NaCl}$ and $1 \mathrm{~g}$ of skimmed milk powder at $21^{\circ} \mathrm{C}$ for $60 \mathrm{~min}$; and c) $2 \mathrm{~g}$ of skimmed milk powder at $60 \mathrm{C}$ for $60 \mathrm{~min}$. Recoveries were similar or higher than $94.7 \%$. This work highlights the importance to adjust extraction procedures regarding the target analyte and food matrix components.

\section{Introduction}

Food allergy is generally mediated by immunoglobulin E and consists in an immunological hypersensitivity against some proteins or glycoproteins of food. Symptoms can involve the gastrointestinal tract, the skin, and/or the respiratory system. Anaphylactic reactions are rarer but of concern, since they are life threatening (Berin \& Sicherer, 2011; Leung \& Kamat, 2008. In addition to symptoms' treatment, food allergies can be controlled by avoiding allergen exposure. Thus, sensitive and selective methods to detect allergens in foodstuffs are extremely important: they can clarify cross-contamination situations during food processing or detect "hidden" allergens in food ingredients Poms, Klein, \& Anklam, 2004).

\footnotetext{
* Corresponding author at: REQUIMTE/LAQV, Departamento de Ciências Químicas, Faculdade de Farmácia, Universidade do Porto, Rua de Jorge Viterbo Ferreira, 228, 4050-313 Porto, Portugal.

E-mail addresses: rita.c.alves@gmail.com (R.C. Alves), filipabpimentel@gmail. com (F.B. Pimentel), hpanouws@gmail.com (H.P.A. Nouws), thenriquekb@gmail. com (T.H.B. Silva), beatoliv@ff.up.pt(M. Beatriz P.P. Oliveira),cmm@isep.ipp.pt (C. Delerue-Matos).
}

Peanut is one of the most allergenic foods. Based on the Directive 2000/13/EC (amended by Directives 2003/89/EC and 2007/68/ $\mathrm{EC})$, in the European Union, and the Food Allergen Labelling and Consumer Protection Act of 2004 (FALCPA 2004, Public Law 108-282, Title II), in the United States, the presence of peanut in a foodstuff has to be declared. Different peanut allergens have been documented by the World Health Organization/ International Union of Immunological Societies Allergen Nomenclature SubCommittee (IUIS, 2016). Ara h 1 (a vicillin-type 7S globulin) was firstly identified as the major peanut allergen, however, several studies showed that Ara h 2 (2S albumin) presented a higher capacity to release histamine from human basophils containing peanut-specific IgE and a higher skin reactivity in peanut-allergic individuals than Ara h 1 (Koppelman, Wensing, Ertmann, Knulst, \& Knol, 2004; Palmer et al., 2005). Recently, Ara h 6 was identified as a relevant allergen since it has also been associated to clinical peanut allergy. Indeed, compared to Ara h 2 , it has a similar seroprevalence and equal capacity to bind and release histamine from basophils (Koid et al., 2014; Koppelman et al., 2005. Moreover, Ara h 2 and Ara h 6 are far more stable to peptic digestion than Ara h 1, which can explain why these proteins are more often recognized 
by IgE in the sera of peanut-allergic individuals Koppelman, Hefle, Taylor, \& de Jong, 2010). Because of its heat resistance and stability against digestion (Hed, 2009; Koppelman et al., 2010, Ara h 6 can be considered an appropriate marker to detect peanut in food products and industrial production lines.

Different methods for food allergen detection are described, namely, protein-based immunoassays Monaci \& Visconti, 2010; Taylor, Nordlee, Niemann, \& Lambrecht, 2009, DNA-based methods (Monaci \& Visconti, 2010; Słowianek \& Majak, 2011, and mass spectrometry (Monaci \& Visconti, 2009). Recently, immuno- and geno-biosensors appeared as interesting alternatives to those methods. They present serious advantages such as reduction of reagents consumption, miniaturization and portability, and reduction of analysis costs (Alves, Barroso, González-García, Oliveira, \& Delerue-Matos, 2016), but their application in this field is still in the beginning.

Nonetheless, besides the detection method, a crucial step in the experimental procedure needs to be considered, especially when analysing foodstuffs, due to their intrinsic chemical complexity: the extraction of the target analyte. Often, an additional purification of the target analyte after extraction is needed before analysis. It is, therefore, crucial to assure that during the entire sample preparation the selected analyte is not destroyed or modified. In the particular case of food allergen detection using immunoassays, sample preparation is an essential step, since several conditions can affect the integrity of the target protein, such as the extraction temperature or the $\mathrm{pH}$ of the extraction solution. Moreover, matrix components could affect the method's result (e.g. non-specific binding), resulting in false positives. On the other hand, if the target molecule is not correctly extracted, a false negative could be obtained (L'Hocine \& Pitre, 2016; Poms, Capelletti, \& Anklam, 2004). These are crucial issues, since in some studies, immunosensors have been developed using a purified allergenic protein standard, but they were not applied to real samples, which makes the method's validation incomplete Huang, Bell, \& Suni, 2008; Singh, Sharma, Baltus, \& Suni, 2010. Besides this, food samples are usually very complex and different from each other and the allergenic proteins differ in their structure, therefore different extraction conditions can lead to huge variations in the quantified amount. Together with the type of antibodies and the assay used, the kind of extraction can also be one of the main reasons why different results are obtained for the same sample using different immunoassay kits (Jayasena et al., 2015).

Because of the increasing clinical relevance that has been given to Ara h 6, in a previous work we developed and validated the first voltammetric (based on a gold nanoparticle-modified screenprinted carbon electrode) immunosensor for Ara h 6 detection in real food matrices (Alves, Pimentel, Nouws, Correr, et al., 2015. Due to the inherent difficulty of analysing proteins in chocolate (Hurst, Krout, \& Burks, 2002; Newsome \& Abbott, 1999; Pomés, Vinton, \& Chapman, 2004, in the present study, we aimed to investigate the best extraction conditions of Ara $\mathrm{h} 6$ from a complex chocolate-based food matrix, by testing different temperatures and extraction times, as well as the inpuence of certain additives ( $\mathrm{NaCl}$ and skimmed milk powder). To the best of our knowledge, this is the ýrst report about the study of the extraction conditions of Ara h 6 for immunoassay detection.

\section{Materials and methods}

\subsection{Chemicals and reagents}

Nitric acid ( $\geqslant 65 \%)$, hydrochloric acid (37\%), sodium chloride, $\beta$-casein $(\geqslant 98 \%), \quad 3$-indoxyl phosphate (3-IP), magnesium nitrate hexahydrate, tris(hydroxymethyl)aminomethane (Tris) and streptavidin-alkaline phosphatase (S-AP) fromStreptomyces avidinii were all obtained from Sigma-Aldrich. The gold $\left(\mathrm{H}\left[\mathrm{AuCl}_{4}\right]\right)$ standard solution was purchased from Merck and silver nitrate was supplied by Alfa Aesar. The mouse monoclonal anti-Ara h 6 IgG1 antibody (3B8), the biotinylated monoclonal anti-Ara h 6 IgG1 antibody (3E12) and the standard Ara h 6 were acquired from Indoor Biotechnologies. Skimmed milk powder was acquired in a local supermarket.

Ultra-pure water (resistivity $=18.2 \mathrm{M} \Omega . \mathrm{cm}$ ) was obtained using a Millipore (Simplicity 185) water purification system.

The solutions of the reagents that were used in the immunoassay were prepared accordingAlves, Pimentel, Nouws, Correr, et al. (2015).

\subsection{Sensor structure and instrumentation}

Screen-printed carbon electrodes (SPCEs, DropSens, Spain), incorporating a conventional three-electrode electrochemical cell $(50 \mu \mathrm{l})$, were used as transducers of the biological reaction. The electrodes' surfaces were nanostructurated with gold nanoparticles by placing $0.1 \mathrm{mM}\left[\mathrm{AuCl}_{4}\right]^{-}$(in $0.1 \mathrm{M} \mathrm{HCl}$ ) on the electrode and applying a current intensity of $-100 \mu \mathrm{A}(240 \mathrm{~s})$, followed by a $0.1 \mathrm{~V}$ potential $(120 \mathrm{~s}$ ) (Alves, Pimentel, Nouws, Correr, et al., 2015). Afterwards, the modified SPCEs were washed with water, dried with a nitrogen stream and stored in the presence of a desiccant. Before their use, the electrodes were rinsed with the $0.1 \mathrm{M}$ Tris- $\mathrm{HNO}_{3}$ buffer ( $\mathrm{pH}$ 7.2).

The electrochemical measurements were performed using a Metrohm Autolab PGSTAT12 potentiostat-galvanostat controlled by GPES4.9 software.

\subsection{Immunosensor assay}

The immunoassay was performed exactly according toAlves, Pimentel, Nouws, Correr, et al. (2015.) Briefly, SPCEs-nAu were coated with a monoclonal anti-Ara h $6 \operatorname{IgG}$ solution $(25 \mu \mathrm{g} / \mathrm{ml})$ and left to incubate overnight at $4^{\circ} \mathrm{C}$. Surface blocking was performed using a $2 \%(w / v) \beta$-casein solution. The sensor was then incubated with a diluted (1:250) sample extract $(40 \mu \mathrm{l})$, an Ara h 6 standard (for calibration) or a Tris- $\mathrm{HNO}_{3} \mathrm{pH} 7.2$ buffer (for the blank assay). Then, the biotinylated monoclonal anti-Ara h 6 IgG $(1: 25,000)$ was left to incubate, followed by S-AP $\left(1 \times 10^{-10} \mathrm{M}\right)$ addition. The enzymatic reaction was carried out using a mixture of 3-IP and silver nitrate $\left(1.0 \times 10^{-3} \mathrm{M}\right.$ and $4.0 \times 10^{-4} \mathrm{M}$, respectively). After $20 \mathrm{~min}$ of reaction, a linear sweep voltammogram was recorded from $-0.02 \mathrm{~V}$ to $+0.4 \mathrm{~V}(50 \mathrm{mV} / \mathrm{s})$. Intermediate steps of rising were always performed before each reagent addition using Tris- $\mathrm{HNO}_{3}$ buffers (Alves, Pimentel, Nouws, Correr, et al., 2015). Analyses were performed in triplicate and measurements were carried out at controlled temperature $(21 \pm \mathrm{PC})$.

\subsection{Samples}

A complex chocolate-based product containing peanut (20\%) was acquired in a local supermarket. The sample also contained milk chocolate, sugar, milk powder and milk proteins, cocoa butter, palm fat, milk fat, starch, glucose, soya lecithin, coconut oil, salt, stabilizing agents, and flavor additives. As negative control, a commercial chocolate without peanut as ingredient (and without any labeled allegation of its potential presence) was used. It also contained the following ingredients: sugar, whole milk powder, skimmed milk powder, cocoa butter, cocoa paste, soya lecithin, palm fat, butter, and flavor additives. 


\subsection{Sample preparation}

Samples were first frozen at $-20^{\circ} \mathrm{C}$ (to avoid melting during milling) and then immediately ground (GM 200, Retsch, Germany) at $10,000 \mathrm{rpm}$ during $20 \mathrm{~s}$ (3x). Different extracts were prepared, in triplicate, using a rigorously weighted amount $\{2.00 \mathrm{~g})$ of powdered sample and $20.00 \pm 0.04 \mathrm{ml}$ of extraction solution (Tris- $\mathrm{HNO}_{3}$ buffer $0.1 \mathrm{M}(\mathrm{A}), \mathrm{pH}=8$ ), with or without the addition of different amounts of $\mathrm{NaCl}(\mathrm{B})$ and/or skimmed milk powder (C). In summary: A) Tris- $\mathrm{HNO}_{3}$ buffer $\left.(\mathrm{pH}=8), \mathrm{B}\right)$ Addition of $\mathrm{NaCl}(0.1$ or $1 \mathrm{M}$ ), C) Addition of skimmed milk powder ( 1 or $2 \mathrm{~g}$ ). The extracts were obtained at controlled time, 15 or $60 \mathrm{~min}$, and temperatures, $21 \pm 1{ }^{\circ} \mathrm{C}$ and $60 \pm 1^{\circ} \mathrm{C}$ (E5CC, Omron Corporation, Kyoto, Japan), under constant magnetic stirring. Subsequently, the samples were subjected to a first centrifugation step (5000 rpm) during $5 \mathrm{~min}$ (Labofuge Ae, Heraeus Sepatech, Germany). An aliquot $(1 \mathrm{ml})$ of the supernatant was further centrifuged at $10,000 \mathrm{rpm}$ for $3 \mathrm{~min}$ (Heraeus Fresco 17 Centrifuge, Thermo Fisher Scientific, Germany) and the resulting supernatant was diluted (1:250) and used in the electrochemical immunoassay. Each extract was analysed in triplicate.

\subsection{Statistical analysis}

Statistical analysis was performed using IBM SPSS v. 20 (IBM Corp., Armonk, 241 NY, USA). Data are expressed as mean \pm standard deviation. The Shapiro-Wilk test was used to evaluate data normality. The one-way ANOVA was used to assess significant differences between samples, followed by Tukey's HSD or Dunett T3 post hoc test (selected based on the equality of the variances) to make pairwise comparisons between means. The level of significance for all hypothesis tests $p$ ) was 0.05 . A hierarchical Cluster analysis was performed using the method of complete linkage (farthest neighbor) with Euclidean distances.

\section{Results and discussion}

Different sample preparation protocols have been used by several authors to perform biosensing detection of different food allergens. Extraction with a pH 7-9 buffer (by vortexing or in an ultrasonic bath) followed by centrifugation is a common procedure (Alves, Pimentel, Nouws, Marques, et al., 2015; Lu, Oshima, \& Ushio, 2004; Maier, Morgan, Lindner, \& Pittner, 2008; Yman, Eriksson, Johansson, \& Hellenas, 2006. Other researchers preferred a commercial allergen extraction buffer (RIDASCREEN ${ }^{\circledR}$, R-Biopharm AG, Darmstadt, Germany) Bremer, Smits, \& Haasnoot, 2009; Raz, Liu, Norde, \& Bremer, 2010 When food products are rich in phenolic compounds, which can bind to allergens and antibodies, skimmed milk powder can be added to eliminate their interference (Pollet et al., 2011). In some cases, the use of $\mathrm{KCl}$ or $\mathrm{NaCl}$ is also employed to improve extraction Wang et al., 2011; Yman et al., 2006). In general, these protocols not only vary according to the sample but also according to the target analyte.

In what concerns to the commercial Enzyme-Linked Immunosorbent Assays (ELISA), several kits from different suppliers are available to detect major peanut allergensJayasena et al. (2015) consider their comparison difficult and unreliable due to the fact that they differ widely from each other in sample extraction procedures, range of quantification, limits of detection and quantification, reference standards used, and results expression. In fact, in a previous study,Zeleny and Schimmel (2010)concluded that the extraction buffer influences the protein yield of extraction. In accordance, Poms, Capelletti, et al. (2004) showed that extraction buffers operating in the $\mathrm{pH}$ range $8-11$ showed the best yields and that elevated roasting temperatures in food processing reduce those values.

In order to evaluate the inpuence of several parameters on the Ara $\mathrm{h} 6$ extraction and detection, different sets of time and temperature were tested, as well as different amounts of the additives (skimmed milk powder and $\mathrm{NaCl}$ ), which are described intable 1. The additives were selected based on their chemical properties: skimmed milk powder has the ability to block phenolic compounds of the matrix (Pomés et al., 2004) and the presence of $\mathrm{NaCl}$ modulates the ionic strength of the solution, which can influence protein solubility (Zayas, 1997).

First, a calibration curve was prepared using the purified Ara h 6 protein and the optimal dilution of the sample extract was studied using two of the extracts described inTable $1: \mathrm{A}\left(21^{\circ} \mathrm{C}, 15 \mathrm{~min}\right)$ and $\mathrm{A} / 1 \mathrm{~B} / 2 \mathrm{C}\left(60^{\circ} \mathrm{C}, 60 \mathrm{~min}\right)$. These were selected because they were obtained using the most 'extreme' conditions. Different dilutions of each extract were then made using the Tris- $\mathrm{HNO}_{3}$ buffer (pH 7), namely $1: 50,1: 100,1: 250,1: 500,1: 1000,1: 2500$, and 1:5000. The 1:250 dilution was selected for all the other analyses, since the peak current intensity $(\mathrm{p}, \mu \mathrm{A})$ obtained for both extracts were slightly below to the intermediate point of the calibration curve. This is important since above a certain concentration (saturation level), in this case $100 \mathrm{ng} / \mathrm{ml}$, the sensor will give similar responses that correspond to the maximumi $\mathrm{p}$ value, and the comparison of the results would be impaired. A linear semi-logarithmic relationship between Ara h 6 concentration ([Ara h 6]) and the $p$ was obtained between 1 and $100 \mathrm{ng} / \mathrm{ml}$ :

$i_{\mathrm{p}}(\mu \mathrm{A})=12.47 \times[$ Ara h 6$]-2.7982, \mathrm{r}=0.9995$

In order to study the influence of temperature and time on Ara $\mathrm{h}$ 6 extraction, the extractions were performed at $21 \pm \mathrm{PC}$ and $60 \pm 1{ }^{\circ} \mathrm{C}$, both during 15 and $60 \mathrm{~min}$. For each set of time and temperature, different amounts of the two additives $(\mathrm{NaCl}$ and skimmed milk powder) were also included Table 1), in a total of 36 different extraction conditions.Table 1 also shows the Ara h 6 concentration ( $\mu \mathrm{g} / \mathrm{g}$ of sample) that was determined using each extraction procedure. As can be observed, the results were variable, with average values ranging from $39.32 \pm 6.50 \mu \mathrm{g} / \mathrm{g}$ (extract 1 : A $\left(21^{\circ} \mathrm{C}, 15 \mathrm{~min}\right)$, using only the Tris- $\mathrm{HNO}_{3}$ buffer $(\mathrm{pH}=8)$ as extraction solution) to $146.31 \pm 27.05 \mu \mathrm{g} / \mathrm{g}$ (extract $17: \mathrm{A} / 1 \mathrm{~B} / 1 \mathrm{C}\left(21^{\circ} \mathrm{C}\right.$, $60 \mathrm{~min}$ ), using Tris- $\mathrm{HNO}_{3}$ buffer in the presence of $1 \mathrm{M} \mathrm{NaCl}$ and $1 \mathrm{~g}$ of skimmed milk powder). These maximum values are in accordance to the expected range of Ara h 6 amounts described in literature, based on the peanut amount of the sample Chen, Wang, ElMezayen, Zhuang, \& Dreskin, 2013; Koppelman et al., 2001; Misra, 2001).

For a better comparison and comprehension of the results, the quantified amounts were grouped and statistically analysedFigs. 1 and 2).

Fig. 1-I shows the influence of time on the extracted amount of Ara $\mathrm{h} 6$ when the extraction was performed at $2 \mathrm{PC}$, using the different extraction mixtures. In general, a time increase from 15 to 60 min maintained or raised the extracted amount of Ara h 6 . Although a general increase tendency was found (certainly due to the increase of the sample/solution contact time), only with the mixture $\mathrm{A} / 2 \mathrm{C}$, which was composed of $2 \mathrm{~g}$ of skimmed milk powder and Tris- $\mathrm{HNO}_{3}$ buffer, the increase was statistically significant $(p<0.05)$. It is clear that the use of some additive proportions was beneficial for Ara h 6 extraction. Indeed, approximately 3-fold higher Ara h 6 amounts were obtained for both extraction times when mixtures $\mathrm{A} / 0.1 \mathrm{~B} / 2 \mathrm{C}$ (containing $0.1 \mathrm{M} \mathrm{NaCl}$ and $2 \mathrm{~g}$ of skimmed milk powder) and $\mathrm{A} / 1 \mathrm{~B} / 1 \mathrm{C}$ (containing $1 \mathrm{M} \mathrm{NaCl}$ and $1 \mathrm{~g}$ of skimmed milk powder) were used, compared to the use of the Tris- $\mathrm{HNO}_{3}$ buffer alone. This is in accordance with a previous study of another peanut allergen (Ara h 1), in which it was noticed 
Table 1

Variation of the Ara h 6 concentration $(\mu \mathrm{g} / \mathrm{g})$ in the commercial chocolate sample containing peanut according to the extraction conditions used.

\begin{tabular}{|c|c|c|c|c|c|c|c|}
\hline $\begin{array}{l}\text { Extract }(\mathrm{n} \\
\left.{ }^{\circ}\right)\end{array}$ & $\begin{array}{l}\text { Extraction conditions } \\
\text { (code) }^{*}\end{array}$ & $\begin{array}{l}\text { Ara h } 6 \text { concentration }(\mu \mathrm{g} / \mathrm{g} \\
\text { sample })\end{array}$ & $\begin{array}{l}\text { CV } \\
(\%)\end{array}$ & $\begin{array}{l}\text { Extract (n } \\
\left.{ }^{\circ}\right)\end{array}$ & $\begin{array}{l}\text { Extraction conditions } \\
\text { (code) })^{*}\end{array}$ & $\begin{array}{l}\text { Ara h } 6 \text { concentration }(\mu \mathrm{g} / \mathrm{g} \\
\text { sample) }\end{array}$ & $\begin{array}{l}\mathrm{CV} \\
(\%)\end{array}$ \\
\hline 1 & $\mathrm{~A}\left(21^{\circ} \mathrm{C}, 15 \mathrm{~min}\right)$ & $39.32 \pm 6.50$ & 16.5 & 19 & $\mathrm{~A}\left(60^{\circ} \mathrm{C}, 15 \mathrm{~min}\right)$ & $48.31 \pm 15.21$ & 31.5 \\
\hline 2 & $\mathrm{~A} / 0.1 \mathrm{~B}\left(21^{\circ} \mathrm{C}, 15 \mathrm{~min}\right)$ & $48.82 \pm 2.96$ & 6.1 & 20 & $\mathrm{~A} / 0.1 \mathrm{~B}\left(60^{\circ} \mathrm{C}, 15 \mathrm{~min}\right)$ & $53.03 \pm 11.98$ & 22.6 \\
\hline 3 & $\mathrm{~A} / 1 \mathrm{~B}\left(21^{\circ} \mathrm{C}, 15 \mathrm{~min}\right)$ & $58.79 \pm 8.41$ & 14.3 & 21 & $\mathrm{~A} / 1 \mathrm{~B}\left(60^{\circ} \mathrm{C}, 15 \mathrm{~min}\right)$ & $96.64 \pm 1.77$ & 1.8 \\
\hline 4 & $\mathrm{~A} / 1 \mathrm{C}\left(21^{\circ} \mathrm{C}, 15 \mathrm{~min}\right)$ & $79.40 \pm 4.37$ & 5.5 & 22 & $\mathrm{~A} / 1 \mathrm{C}\left(60^{\circ} \mathrm{C}, 15 \mathrm{~min}\right)$ & $116.38 \pm 2.77$ & 2.4 \\
\hline 5 & $\mathrm{~A} / 2 \mathrm{C}\left(21^{\circ} \mathrm{C}, 15 \mathrm{~min}\right)$ & $53.97 \pm 9.33$ & 17.3 & 23 & $\mathrm{~A} / 2 \mathrm{C}\left(60^{\circ} \mathrm{C}, 15 \mathrm{~min}\right)$ & $109.05 \pm 17.96$ & 16.5 \\
\hline 6 & $\mathrm{~A} / 0.1 \mathrm{~B} / 1 \mathrm{C}\left(21^{\circ} \mathrm{C}, 15 \mathrm{~min}\right)$ & $54.15 \pm 11.02$ & 20.4 & 24 & $\mathrm{~A} / 0.1 \mathrm{~B} / 1 \mathrm{C}\left(60^{\circ} \mathrm{C}, 15 \mathrm{~min}\right)$ & $69.12 \pm 0.35$ & 0.5 \\
\hline 7 & $\mathrm{~A} / 0.1 \mathrm{~B} / 2 \mathrm{C}\left(21^{\circ} \mathrm{C}, 15 \mathrm{~min}\right)$ & $121.94 \pm 19.42$ & 15.9 & 25 & $\mathrm{~A} / 0.1 \mathrm{~B} / 2 \mathrm{C}(60 \mathrm{C}, 15 \mathrm{~min})$ & $95.85 \pm 15.56$ & 16.2 \\
\hline 8 & $\mathrm{~A} / 1 \mathrm{~B} / 1 \mathrm{C}\left(21^{\circ} \mathrm{C}, 15 \mathrm{~min}\right)$ & $105.74 \pm 19.20$ & 18.2 & 26 & $\mathrm{~A} / 1 \mathrm{~B} / 1 \mathrm{C}\left(60^{\circ} \mathrm{C}, 15 \mathrm{~min}\right)$ & $60.28 \pm 11.43$ & 19.0 \\
\hline 9 & $\mathrm{~A} / 1 \mathrm{~B} / 2 \mathrm{C}\left(21^{\circ} \mathrm{C}, 15 \mathrm{~min}\right)$ & $82.87 \pm 13.59$ & 16.4 & 27 & $\mathrm{~A} / 1 \mathrm{~B} / 2 \mathrm{C}\left(60^{\circ} \mathrm{C}, 15 \mathrm{~min}\right)$ & $87.31 \pm 13.50$ & 15.5 \\
\hline 10 & $\mathrm{~A}\left(21^{\circ} \mathrm{C}, 60 \mathrm{~min}\right)$ & $48.20 \pm 4.69$ & 9.7 & 28 & $\mathrm{~A}\left(60^{\circ} \mathrm{C}, 60 \mathrm{~min}\right)$ & $47.43 \pm 5.71$ & 12.0 \\
\hline 11 & $\mathrm{~A} / 0.1 \mathrm{~B}\left(21^{\circ} \mathrm{C}, 60 \mathrm{~min}\right)$ & $55.09 \pm 12.24$ & 22.2 & 29 & $\mathrm{~A} / 0.1 \mathrm{~B}\left(60^{\circ} \mathrm{C}, 60 \mathrm{~min}\right)$ & $50.54 \pm 5.47$ & 10.8 \\
\hline 12 & $\mathrm{~A} / 1 \mathrm{~B}\left(21^{\circ} \mathrm{C}, 60 \mathrm{~min}\right)$ & $51.22 \pm 8.87$ & 17.3 & 30 & $\mathrm{~A} / 1 \mathrm{~B}\left(60^{\circ} \mathrm{C}, 60 \mathrm{~min}\right)$ & $39.09 \pm 6.80$ & 17.4 \\
\hline 13 & $\mathrm{~A} / 1 \mathrm{C}\left(21^{\circ} \mathrm{C}, 60 \mathrm{~min}\right)$ & $88.60 \pm 10.40$ & 11.7 & 31 & $\mathrm{~A} / 1 \mathrm{C}\left(60^{\circ} \mathrm{C}, 60 \mathrm{~min}\right)$ & $73.28 \pm 14.14$ & 19.3 \\
\hline 14 & $\mathrm{~A} / 2 \mathrm{C}\left(21^{\circ} \mathrm{C}, 60 \mathrm{~min}\right)$ & $105.76 \pm 14.57$ & 13.8 & 32 & $\mathrm{~A} / 2 \mathrm{C}\left(60^{\circ} \mathrm{C}, 60 \mathrm{~min}\right)$ & $145.27 \pm 23.19$ & 16.0 \\
\hline 15 & $\mathrm{~A} / 0.1 \mathrm{~B} / 1 \mathrm{C}\left(21^{\circ} \mathrm{C}, 60 \mathrm{~min}\right)$ & $52.52 \pm 11.33$ & 21.6 & 33 & $\mathrm{~A} / 0.1 \mathrm{~B} / 1 \mathrm{C}\left(60^{\circ} \mathrm{C}, 60 \mathrm{~min}\right)$ & $86.26 \pm 22.26$ & 25.8 \\
\hline 16 & $\mathrm{~A} / 0.1 \mathrm{~B} / 2 \mathrm{C}\left(21^{\circ} \mathrm{C}, 60 \mathrm{~min}\right)$ & $145.86 \pm 24.03$ & 16.5 & 34 & $\mathrm{~A} / 0.1 \mathrm{~B} / 2 \mathrm{C}\left(60^{\circ} \mathrm{C}, 60 \mathrm{~min}\right)$ & $82.69 \pm 5.93$ & 7.2 \\
\hline 17 & $\mathrm{~A} / 1 \mathrm{~B} / 1 \mathrm{C}\left(21^{\circ} \mathrm{C}, 60 \mathrm{~min}\right)$ & $146.31 \pm 27.05$ & 18.5 & 35 & $\mathrm{~A} / 1 \mathrm{~B} / 1 \mathrm{C}\left(60^{\circ} \mathrm{C}, 60 \mathrm{~min}\right)$ & $59.80 \pm 10.15$ & 17.0 \\
\hline 18 & $\mathrm{~A} / 1 \mathrm{~B} / 2 \mathrm{C}\left(21^{\circ} \mathrm{C}, 60 \mathrm{~min}\right)$ & $99.12 \pm 2.20$ & 2.2 & 36 & $\mathrm{~A} / 1 \mathrm{~B} / 2 \mathrm{C}\left(60^{\circ} \mathrm{C}, 60 \mathrm{~min}\right)$ & $61.19 \pm 7.88$ & 12.9 \\
\hline
\end{tabular}

Mean \pm standard deviation, calculated analysing three extracts prepared in different days. Each extract was analysed in triplicate (total of repties: $n=9$ ).

A, only Tris- $\mathrm{HNO}_{3}$ buffer ( $\mathrm{pH}=8$ ); $\mathbf{A} / \mathbf{0 . 1 B}$, Tris- $\mathrm{HNO}_{3}$ with $0.1 \mathrm{M} \mathrm{NaCl} ; \mathbf{A} / \mathbf{1 B}$, Tris-HNO 3 with $1 \mathrm{M} \mathrm{NaCl} ; \mathbf{A} / \mathbf{1 C}$ Tris-HNO $\mathrm{H}_{3}$ with $1 \mathrm{~g}$ of skimmed milk powder;A/2C Tris-HNO 3

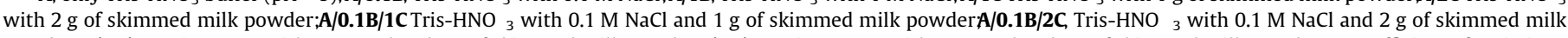

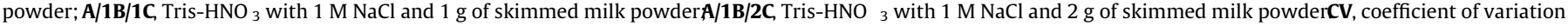
(\%).
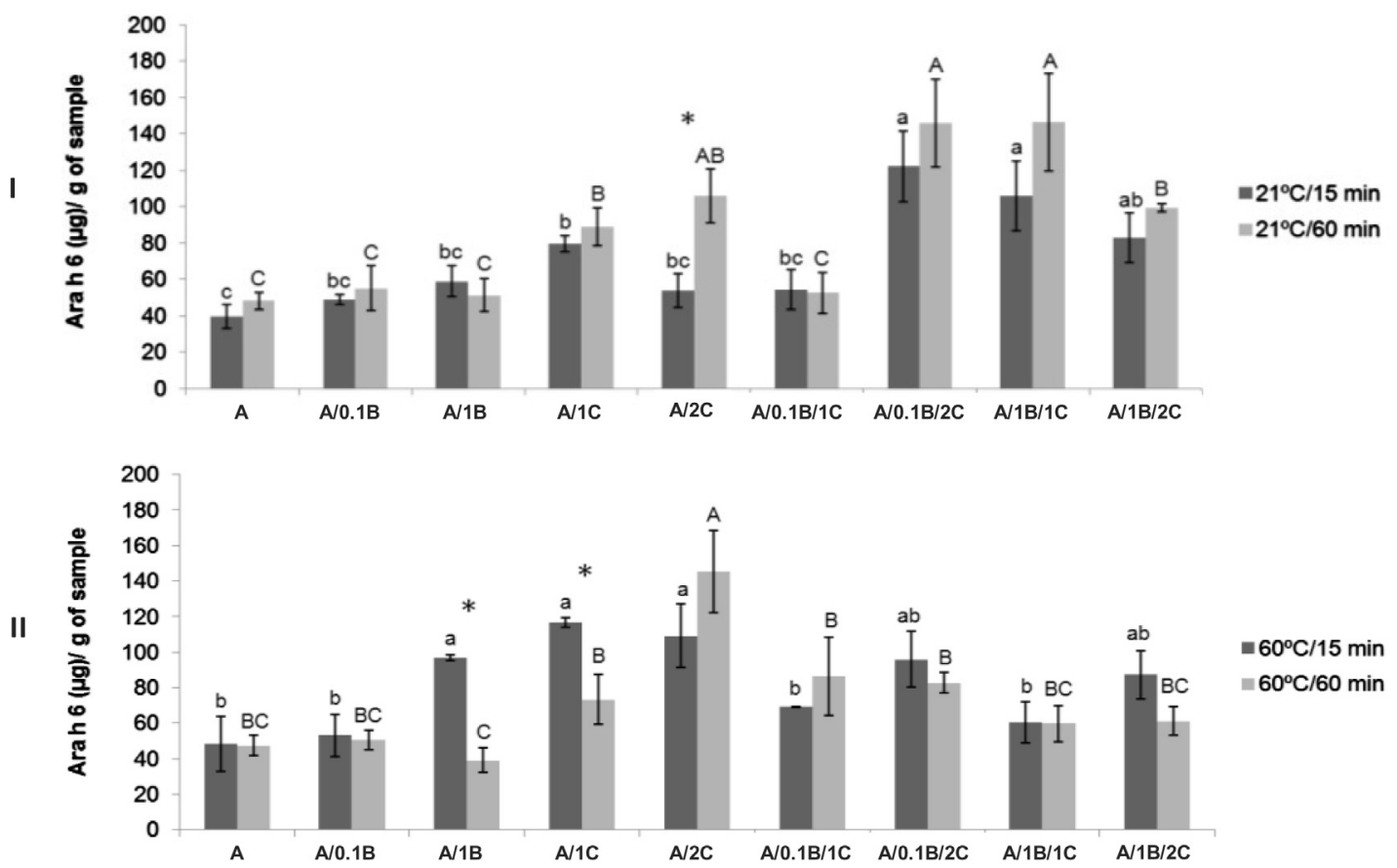

Fig. 1. Influence of extraction time ( 15 and $60 \mathrm{~min}$ ) on the Ara h 6 amount ( $\mu \mathrm{g}$ ) extracted from a chocolate commercial sample containing peanut at $29 \mathrm{C}(\mathrm{I})$ and at $60{ }^{\circ} \mathrm{C}$ (II).

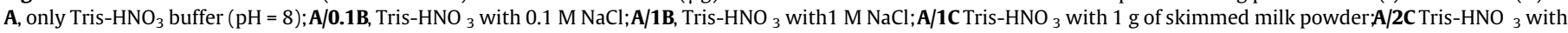

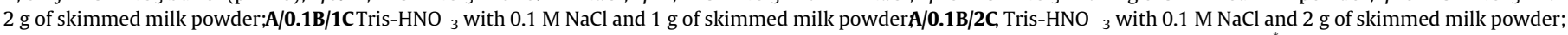

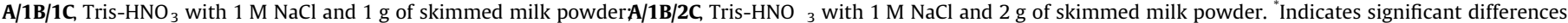
$\left(p<0.05\right.$ ) between $21^{\circ} \mathrm{C} / 15 \mathrm{~min}$ and $21^{\circ} \mathrm{C} / 60 \mathrm{~min}(\mathbf{I})$ or between $60^{\circ} \mathrm{C} / 15 \mathrm{~min}$ and $60^{\circ} \mathrm{C} / 60 \mathrm{~min}$ (II), for the same extraction mixture. Different small letters above left columns indicate significant differences $k<0.05$ ) between different extraction mixtures used at $2 \mathrm{PC} / 15 \mathrm{~min}(\mathbf{I})$ or $60^{\circ} \mathrm{C} / 15 \mathrm{~min}(\mathbf{I I})$. Different capital letters above right columns indicate significant differences $k<0.05)$ between different extraction mixtures used at $2 \mathrm{PC} / 60 \mathrm{~min}(\mathrm{I})$ or $60^{\circ} \mathrm{C} / 60 \mathrm{~min}(\mathrm{II})$.

that chocolate impaired its detection when foods were extracted without additives (Pomés et al., 2003). The authors concluded that this allergen should be extracted from chocolate products in the presence $5 \%$ of nonfat dry milk Pomés et al., 2004).

By comparing the 15-min extractions at both temperatures (Fig. 2-I), in general, fast 'hot' extractions were better when using only one additive: signiýcantly higher results $\not<<0.05)$ were obtained at $60^{\circ} \mathrm{C}$ for three extraction mixtures, namely $\mathrm{A} / 1 \mathrm{~B}$ (inclusion of $1 \mathrm{M} \mathrm{NaCl}$ ), $\mathrm{A} / 1 \mathrm{C}$ (addition of $1 \mathrm{~g}$ of skimmed milk powder) and $\mathrm{A} / 2 \mathrm{C}$ (addition of $2 \mathrm{~g}$ of skimmed milk powder). In contrast, when using $\mathrm{A} / 0.1 \mathrm{~B} / 2 \mathrm{C}$ (combination of $0.1 \mathrm{M} \mathrm{NaCl}$ and $2 \mathrm{~g}$ of skimmed milk powder) and $\mathrm{A} / 1 \mathrm{~B} / 1 \mathrm{C}$ (combination of $1 \mathrm{M}$ 

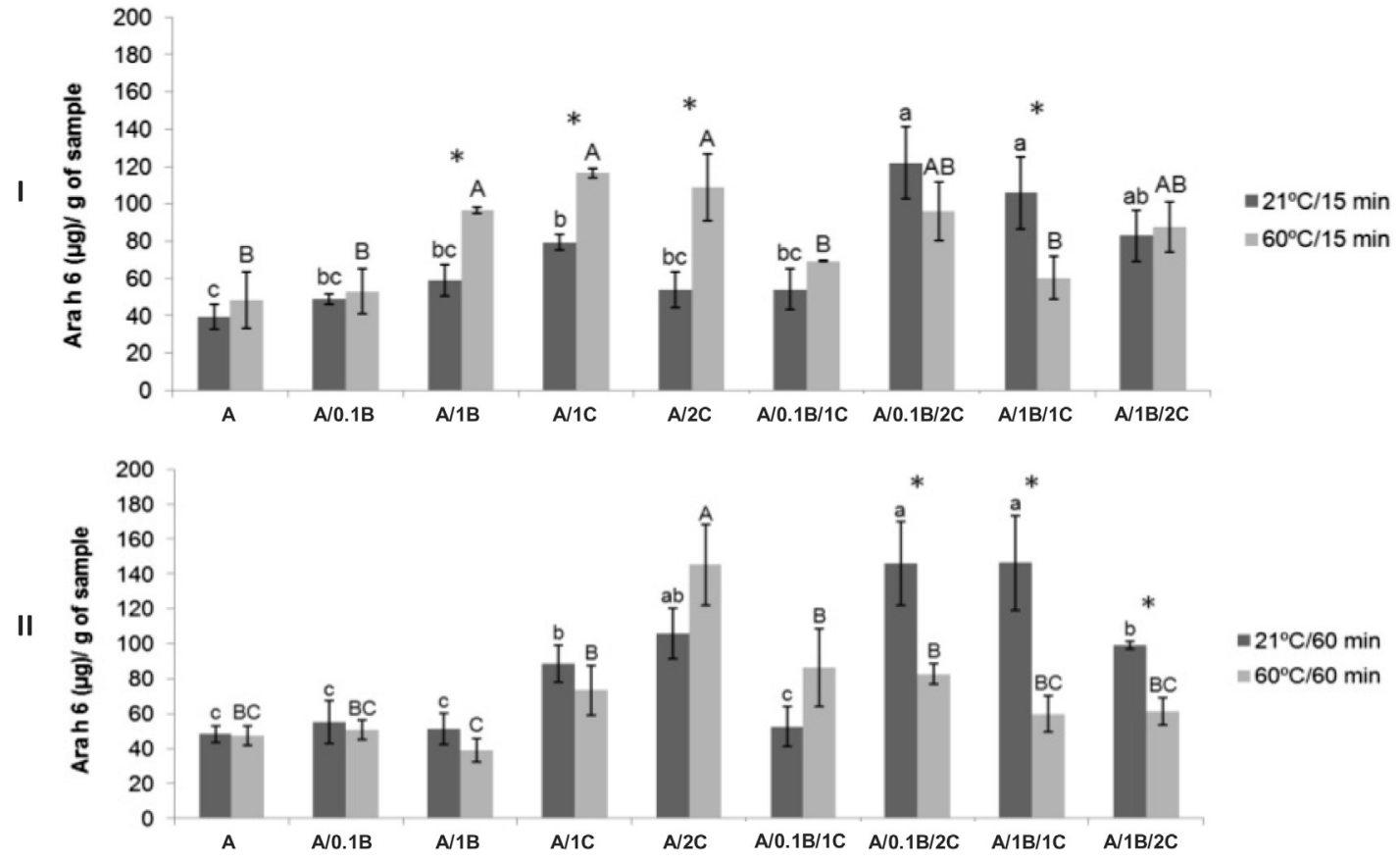

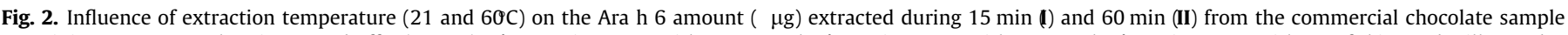

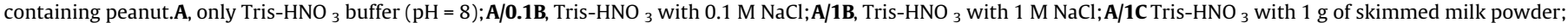

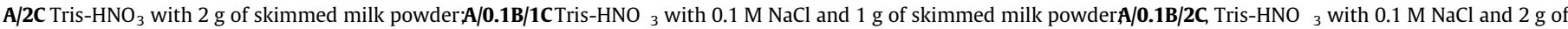

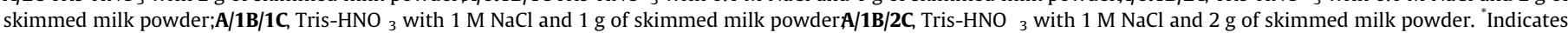
significant differences $\left(p<0.05\right.$ ) between $21^{\circ} \mathrm{C} / 15 \mathrm{~min}$ and $60^{\circ} \mathrm{C} / 15 \mathrm{~min}$ (I) or $21^{\circ} \mathrm{C} / 60 \mathrm{~min}$ and $60^{\circ} \mathrm{C} / 60 \mathrm{~min}$ (II), for the same extraction mixture. Different small letters above left columns indicate significant differences $k<0.05$ ) between different extraction mixtures used at $2 \mathrm{PC} / 15 \mathrm{~min}(\mathrm{I})$ or $21^{\circ} \mathrm{C} / 60 \mathrm{~min}$ (II). Different capital letters above right columns indicate significant differences $\not k<0.05)$ between different extraction mixtures used at $60 \mathrm{C} / 15 \mathrm{~min}(\mathbf{I})$ or $60{ }^{\circ} \mathrm{C} / 60 \mathrm{~min}(\mathbf{I I})$.

$\mathrm{NaCl}$ and $1 \mathrm{~g}$ of skimmed milk powder), the obtained results were higher when the extractions were performed at room temperature. For all the remaining extractions, similar results were achieved using both temperatures, as detailed inFig. 2-I.

For long extractions (60 $\mathrm{min})$, comparing both temperatures (Fig. 2-II), significantly lower $(p<0.05)$ amounts of Ara h 6 were quantified when using the mixtures $\mathrm{A} / 0.1 \mathrm{~B} / 2 \mathrm{C}(0.1 \mathrm{M} \mathrm{NaCl}$ and $2 \mathrm{~g}$ of skimmed milk powder), $\mathrm{A} / 1 \mathrm{~B} / 1 \mathrm{C}(1 \mathrm{M} \mathrm{NaCl}$ and $1 \mathrm{~g}$ of skimmed milk powder), and $\mathrm{A} / 1 \mathrm{~B} / 2 \mathrm{C}(1 \mathrm{M} \mathrm{NaCl}$ and $2 \mathrm{~g}$ of skimmed milk powder) at $60^{\circ} \mathrm{C}$. Compared to extractions at $21^{\circ} \mathrm{C}$, an increase of the average allergen amount (although not statistically significant) was obtained at the higher temperature, using the mixtures $\mathrm{A} / 2 \mathrm{C}$ ( $2 \mathrm{~g}$ of skimmed milk powder) and $\mathrm{A} / 0.1 \mathrm{~B} / 1 \mathrm{C}(0.1 \mathrm{M} \mathrm{NaCl}$ and $1 \mathrm{~g}$ of skimmed milk powder). For the remaining extractions, no significant differences were observed using different extraction temperatures Fig. 2-II).

A hierarchical clustering analysis, considering the extraction parameters as variables, showed that the operating conditions can be allocated into 7 main groups, according to the dendrogram presented in Fig. 3. In complete-linkage clustering (the methodology used), the link between two clusters contains all element pairs, and the distance between clusters equals the distance between those two elements (one in each cluster) that are farthest away from each other. The shortest of these links that remains at any step causes the fusion of the two clusters whose elements are involved (Yashwant \& Sananse, 2015). The clusters obtained in Fig. 3 may be arranged, considering the decreasing order of Ara $h$ 6 amount, as follows: Cluster $3>$ Cluster $2>$ Cluster $1>$ Cluster $5>$ Cluster $4>$ Cluster $7>$ Cluster 6 .

Cluster 3 groups the set of conditions (no significant differences between them) that allowed the highest amount of Ara $\mathrm{h} 6$ from the chocolate-based matrix. These are A/0.1B/2C (2PC, $60 \mathrm{~min}$ ): $145.86 \pm 24.03 \mu \mathrm{g} / \mathrm{g} ; \mathrm{A} / 1 \mathrm{~B} / 1 \mathrm{C}\left(21^{\circ} \mathrm{C}, 60 \mathrm{~min}\right): 146.31 \pm 27.05 \mu \mathrm{g} /$ g; and $\mathrm{A} / 2 \mathrm{C}\left(60^{\circ} \mathrm{C}, 60 \mathrm{~min}\right): 145.27 \pm 23.19 \mu \mathrm{g} / \mathrm{g}$. Cluster 2 was composed of two sets of conditions $-\mathrm{A} / 0.1 \mathrm{~B} / 2 \mathrm{C}$ (2PC, $15 \mathrm{~min}$ ) and $\mathrm{A} / 1 \mathrm{C}\left(60^{\circ} \mathrm{C}, 15 \mathrm{~min}\right)$ - that allowed the extraction of slightly lower amounts $(121.94 \pm 19.42$ and $116.38 \pm 2.77 \mu \mathrm{g} / \mathrm{g}$, respectively). This was followed by Cluster 1 composed of six different sets of conditions, namely $8,14,18,21,23$, and 25 (detailed in Table 1), in which Ara $\mathrm{h} 6$ concentration varied from $95.85 \pm 15.56$ to $105.74 \pm 19.20 \mu \mathrm{g} / \mathrm{g}$ and Cluster 5 (also constituted by six type of different extracts,Fig. 3) with minimum and maximum Ara h 6 amounts of $79.40 \pm 4.37$ and $88.60 \pm 10.40 \mu \mathrm{g} /$ g. Cluster 7 groups a great number of different extraction conditions (fifteen) that all gave Ara $\mathrm{h} 6$ concentrations between $47.43 \pm 5.71$ and $61.19 \pm 7.88 \mu \mathrm{g} / \mathrm{g}$. Finally, the use of the following operating conditions $-\mathrm{A}\left(21^{\circ} \mathrm{C}, 15 \mathrm{~min}\right)$ and $\mathrm{A} / 1 \mathrm{~B}\left(60^{\circ} \mathrm{C}, 60 \mathrm{~min}\right)-$ showed to be the more inefficient to extract Ara h 6 from chocolate since in both cases less than $40 \mu \mathrm{g} / \mathrm{g}$ were detected.

Although the capacity of this sensor to detect and quantify Ara h 6 in real complex food samples was already tested and validated in a previous work (Alves, Pimentel, Nouws, Correr, et al., 2015, it was also important to find if the extraction mixtures selected as the best ones (Cluster 3,Fig. 3) could in some way interfere with the protein detection. Thus, blank extracts (without sample) were prepared and analysed showing similar results (no significant differences, $p>0.05$ ) compared to the usual blank of the assay (using only Tris- $\mathrm{HNO}_{3}$ buffer). Based on this, any possibility of interference of these extraction mixtures in this immunosensing detection can be excluded.

Besides, for the best extraction conditions (17), recoveries were also evaluated. For that, sample aliquots were spiked with 25,50 or $75 \%$ of the expected Ara h 6 amount (standard). Then, spiked and non-spiked aliquots were extracted using those conditions. Extracts were analysed and recoveries calculated. For all the three levels, recoveries were similar or higher than $94.7 \%$. 


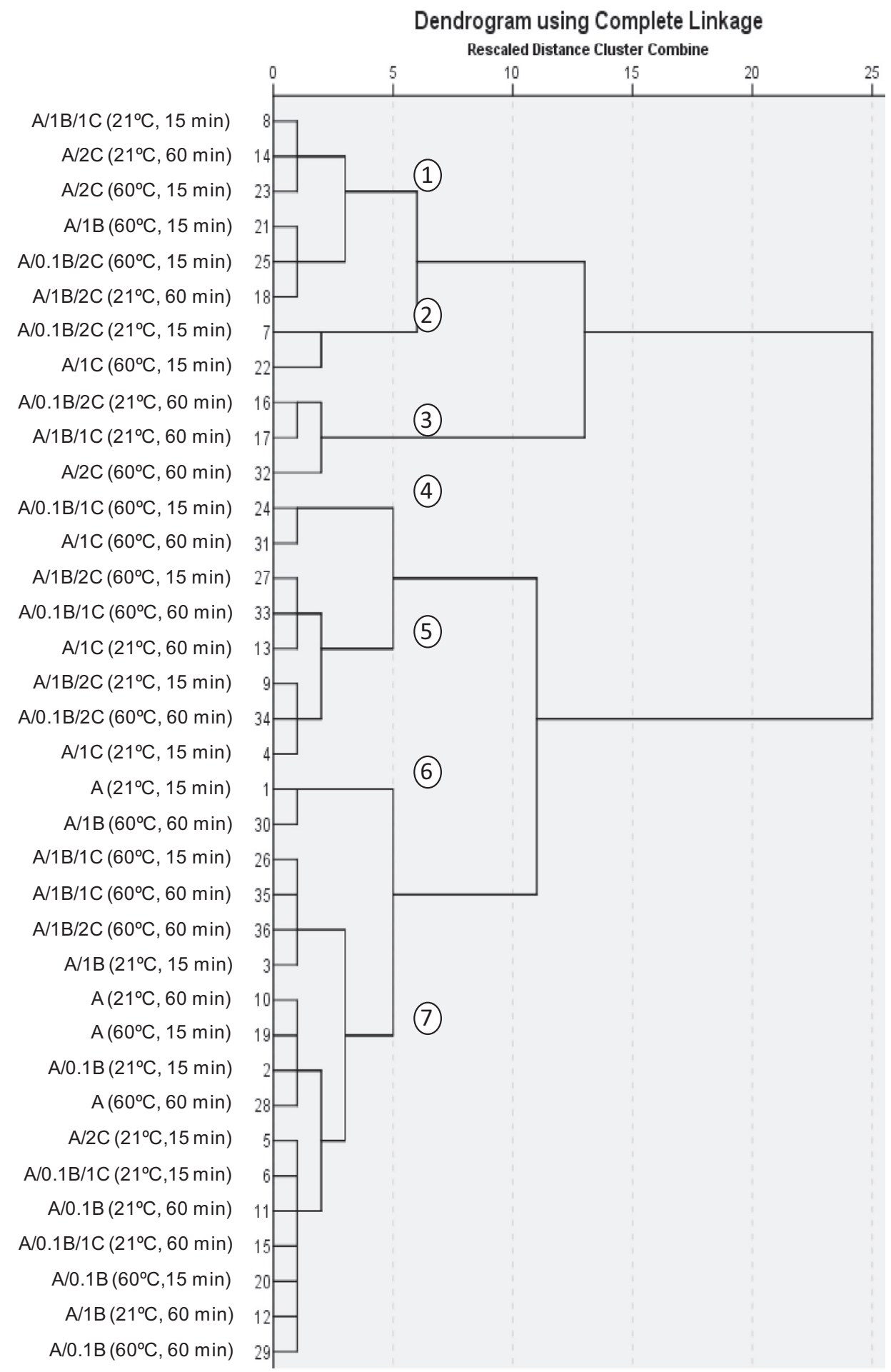

Fig. 3. Dendrogram resulting from a cluster analysis of the different extraction conditions tested. The set of conditions that correspond to each extractnmbrer are detailed in Table 1.

\section{Conclusions}

In this work, different extraction conditions were tested in order to increase the extractability and detection of Ara h 6. The results of this work show that the use of additives can significantly increase Ara h 6 extraction, and that long extractions (60 min) are generally more effective than short ones (15 min), except in some of the cases (at $60^{\circ} \mathrm{C}$ ), in which the use of this temperature resulted in a decrease of the amount of extracted protein. Based on the cluster analysis, three sets of conditions were selected as the best ones since they allowed the extraction of the highest amounts of Ara h 6 . This work highlights the importance of sample preparation and the need to adjust extraction procedures, taking into consideration not only the target analyte but also the components of the food matrix. This is a relevant issue regarding those commercial immunoassay kits that contain only one extraction 
buffer/solution to perform food allergen extraction from different food samples.

\section{Conflict of interest}

The authors state that there are no conflicts of interest.

\section{Acknowledgments}

Rita C. Alves is grateful toFundação para a Ciência e a Tecnologia (FCT) for a post-doctoral research grant (SFRH/BPD/68883/2010), financed by National Funds Ministério da Educação e da Ciêncià and by the European Social Fund through POCHPrograma Operacional Capital Humano The authors thank the financial support to the project Operação NORTE-01-0145-FEDER-000011 - Qualidade e Segurança Alimentar- uma abordagem (nano)tecnológica. This work was also supported by the project UID/QUI/50006/2013 $\mathrm{POCI} / 01 / 0145 /$ FEDER/007265 with financial support from FCT/ MEC through national funds and co-financed by FEDER.

\section{References}

Alves, R. C., Pimentel, F. B., Nouws, H. P., Correr, W. González-García, M. B., Oliveira, M. B. P. P., et al. (2015a). Detection of the peanut allergen Ara h 6 in foodstuffs using a voltammetric biosensing approach. Analytical and Bioanalytical Chemistry, 407, 7157-7163.

Alves, R. C., Pimentel, F. B., Nouws, H. P., Marques, R. C., González-García, M. B., Oliveira, M. B. P. P., et al. (2015b). Detection of Ara h 1 (a major peanut allergen) in food using an electrochemical gold nanoparticle-coated screen-printed immunosensor. Biosensors and Bioelectronics, 6419-24.

Alves, R. C., Barroso, M., González-García, M. B., Oliveira, M. B. P. P., \& DelerueMatos, C. (2016). New trends in food allergens detection: towards biosensing strategies. Critical Reviews in Food Science and Nutrition, 252304-2319. http:// dx.doi.org/10.1080/10408398.2013.831026

Berin, M. C., \& Sicherer, S. (2011). Food allergy: Mechanisms and therapeutics. Current Opinion in Immunology, $23794-800$.

Bremer, M. G. E. G., Smits, N. G. E., \& Haasnoot, W. (2009). Biosensor immunoassay for traces of hazelnut protein in olive oilAnalytical and Bioanalytical Chemistry, 395, 119-126.

Chen, X., Wang, Q., El-Mezayen, R., Zhuang, Y., \& Dreskin, S. C. (2013). Ara h 2 and Ara h 6 have similar allergenic activity and are substantially redundant. International Archives of Allergy and Immunology, 16,0251-258.

Hed, J. (2009). Cross-reactivity in plant food allergy - Clinical impact of component resolved diagnostics (CRD) Sweden: Phadia $A B$

Huang, Y., Bell, M. C., \& Suni, I. I. (2008). Impedance biosensor for peanut protein Ara h 1. Analytical Chemistry, 8Q 9157-9161.

Hurst, W. J., Krout, E. R., \& Burks, W. R. (2002). A comparison of commercially available peanut Elisa test kits on the analysis of samples of dark and milk chocolate. Journal of Immunoassay and Immunochemistry, 23451-459.

IUIS Allergen Nomenclature Sub-committee. Allergen nomenclature. Available in: $<$ http://www.allergen.org > Accessed in 20 Jan 2016.

Jayasena, S., Smits, M., Fiechter, D., de Jong, A., Nordlee, J., Baumert, J., et al. (2015). Comparison of six commercial ELISA kits for their specificity and sensitivity in detecting different major peanut allergens.Journal of Agricultural and Food Chemistry, 63, 1849-1855.

Koid, A. E., Chapman, M. D., Hamilton, R. G., van Ree, R., Versteeg, S. A., Dreskin, S. C., et al. (2014). Ara h 6 complements Ara h 2 as an important marker for IgE reactivity to peanut.Journal of Agricultural and Food Chemistry, 62206-213.

Koppelman, S. J., Vlooswijk, R. A., Knippels, L. M., Hessing, M., Knol, E. F., van Reijsen, F. C., et al. (2001). Quantification of major peanut allergens Ara h 1 and Ara h 2 in the peanut varieties Runner, Spanish, Virginia, and Valencia, bred in different parts of the world.Allergy, 56, 132-137.

Koppelman, S. J., de Jong, G. A., Laaper-Ertmann, M., Peeters, K. A., Knulst, A. C., Hefle, S. L., et al. (2005). Purification and immunoglobulin E-binding properties of peanut allergen Ara h 6: evidence for cross-reactivity with Ara h 2Clinical and Experimental Allergy, 35 490-497.
Koppelman, S. J., Wensing, M., Ertmann, M., Knulst, A. C., \& Knol, E. F. (2004). Relevance of Ara h1, Ara h2 and Ara h3 in peanut allergic patients, as determined by immunoglobulin E Western blotting, basophil-histamine release and intracutaneous testing: Ara h2 is the most important peanut allergen. Clinical and Experimental Allergy, 34 583-590.

Koppelman, S. J., Hefle, S. L., Taylor, S. L., \& de Jong, G. A. (2010). Digestion of peanut allergens Ara h 1, Ara h 2, Ara h 3, and Ara h 6: A comparative in vitro study and partial characterization of digestion-resistant peptidesMolecular Nutrition and Food Research, 54, 1711-1721.

Leung, A., \& Kamat, D. (2008). Clinical manifestations of food allergy. In C. M. Chesterton (Ed.),Food allergies: New research(pp. 91-120). New York: Ed. Nova Science Publishers Inc..

L'Hocine, L., \& Pitre, M. (2016). Quantitative and qualitative optimization of allergen extraction from peanut and selected tree nuts. Part 2. Optimization of buffer and ionic strength using a full factorial experimental designFood Chemistry, $194,820-827$

Lu, Y., Oshima, T., \& Ushio, H. (2004). Rapid detection of fish major allergen parvalbumin by surface plasmon resonance biosensor.Food Chemistry and Toxicology, 69, C652-C657.

Maier, I., Morgan, M. R., Lindner, W., \& Pittner, F. (2008). Optical resonance enhanced absorption-based near-field immunochip biosensor for allergen detection. Analytical Chemistry, 80 2694-2703.

Misra, J. B. (2001). Variation in nitrogen-to-protein conversion factor for peanut. Peanut Science, 28,48-51.

Monaci, L., \& Visconti, A. (2009). Mass spectrometry-based proteomics methods for analysis of food allergens.Trends in Analytical Chemistry, 28581-591.

Monaci, L., \& Visconti, A. (2010). Immunochemical and DNA-based methods in food allergen analysis and quality assurance perspectivesTrends in Food Science and Technology, 21, 272-283.

Newsome, W. H., \& Abbott, M. (1999). An immunoaffinity column for the determination of peanut protein in chocolate.Journal of AOAC International, 82, 666-668.

Palmer, G. W., Dibbern, D. A., Jr., Burks, A. W., Bannon, G. A., Bock, S. A., Porterfield H. S., et al. (2005). Comparative potency of Ara h 1 and Ara h 2 in immunochemical and functional assays of allergenicityClinical Immunology, $115,302-312$

Pollet, J., Delport, F., Janssen, K. P., Tran, D., Wouters, J., Verbiest, T., et al. (2011). Fast and accurate peanut allergen detection with nanobead enhanced optical fiber SPR biosensor. Talanta, 83, 1436-1441.

Pomés, A., Helm, R. M., Bannon, G. A., Burks, A. W., Tsay, A., \& Chapman, M. D. (2003). Monitoring peanut allergen in food products by measuring Ara $\mathrm{h} 1$. Journal of Allergy and Clinical Immunology, 11,1640-645.

Pomés, A., Vinton, R., \& Chapman, M. D. (2004). Peanut allergen (Ara h 1) detection in foods containing chocolate.Journal of Food Protection, 67, 793-798.

Poms, R. E., Klein, C. L., \& Anklam, E. (2004a). Methods for allergen analysis in food: A review. Food Additives \& Contaminants, 211-31.

Poms, R. E., Capelletti, C., \& Anklam, E. (2004b). Effect of roasting history and buffer composition on peanut protein extraction efficiencyMolecular Nutrition E Food Research, 48, 459-464.

Raz, S. R., Liu, H., Norde, W., \& Bremer, M. G. (2010). Food allergens profiling with an imaging surface plasmon resonance-based biosensorAnalytical Chemistry, 82 8485-8491.

Singh, R., Sharma, P. P., Baltus, R. E., \& Suni, I. I. (2010). Nanopore immunosensor for peanut protein Ara h1.Sensors and Actuators B, 145 98-103.

Słowianek, M., \& Majak, I. (2011). Methods of allergen detection based on DNA analysis. Biotechnology and Food Science, 75 39-44.

Taylor, S. L., Nordlee, J. A., Niemann, L. M., \& Lambrecht, D. M. (2009). Allergen immunoassays-considerations for use of naturally incurred standards. Analytical and Bioanalytical Chemistry, 39583-92.

Wang, W., Han, J., Wu, Y., Yuan, F., Chen, Y., \& Ge, Y. (2011). Simultaneous detection of eight food allergens using optical thin-film biosensor chips.Journal of Agricultural and Food Chemistry, 596889-6894.

Yashwant, S., \& Sananse, S. L. (2015). Comparisons of different methods of cluster analysis with application to rainfall data.International Journal of Innovative Research in Science, Engineering and Technology, 410861-10872

Yman, I., Eriksson, A., Johansson, M., \& Hellenas, K. (2006). Food allergen detection with biosensor immunoassays.Journal of AOAC International, 89 856-861.

Zayas, J. F. (1997). Solubility of proteins. In J. F. Zayas (Ed.)Functionality of proteins in food (pp. 6-75). New York: Springer-Verlag, Berlin Heidelberg

Zeleny, R., \& Schimmel, H. (2010). Towards comparability of ELISA results for peanut proteins in food: A feasibility study.Food Chemistry, 123,1343-1351. 